\title{
Stained Glass: An Afterword
}

Isobel Armstrong

This welcome collection of articles on stained glass in the nineteenth century must be a first. A symposium specifically on coloured glass has not, to my knowledge, appeared before, certainly not so far in the twenty-first century.

Coloured glass has had a slow recognition. I wonder how many of the following names (jotted down as I encountered them in these articles), well known in the nineteenth-century stained glass community, would be known by nineteenth-century scholars today: Christopher Whall, Charles Winston, N. H. J. Westlake, Lewis Foreman Day, Reuben Townroe, Chance Brothers and Co., T. W. Camm, Georges Bontemps, James Powell \& Sons, Charles Eamer Kempe, John Richard Clayton, and Henry Holiday. William Morris and Edward Burne-Jones, of course, and perhaps other Pre-Raphaelites, will come to mind before these figures, and probably only these names. But there is nothing invidious about this lack of recognition: the art of coloured glass was created by the coming together of a range of figures - glaziers and artisans, technicians of glassmaking, chemists, designers, architects, artists, commercial and specialist glassmaking firms, patrons, donors, planners, and treatise-writers. A public coloured glass window, and even domestic glass, could not be created without the collaboration of all or some of these agents. Coloured glass, as the product of both artist and artisan, does not fit into our accustomed paradigms and hierarchies of aesthetic creation and so we have no context for it. This group of articles aims to create this context and makes it clear that the production of coloured glass was a complex process - part industrial, part individual - and where attention to public taste and experience was often crucial. That is why Jasmine Allen's remark that coloured glass was an ideological medium is important. Right from the start stained coloured glass was a predominantly public form on display whether it took the shape of a window or a fairground decoration - or even a glass necklace.

It has not helped, perhaps, that the designation 'stained glass' is misleading. Glass was either coloured from within or painted from without. Some glass windows were constructed as mosaics of different coloured glass, held in place by leadlines. The glass used was 'pot metal', metal being the trade name for glass, which had been subjected to intense heat in the furnace, like any clear glass, except that the molten glass was coloured 
with added powdered metals. Thus, the colour was intrinsic to it, not an external stain. Painted glass was literally painted: it was made by using vitreous paints and enamels to create images on clear glass on analogy with pictorial painting techniques. Both kinds of glass were translucent and light-transmitting. And the confusing aspect of the categories is that coloured mosaic glass could be drawn on and painted in part (for instance, faces). But the two types of glass are different and almost certainly ask for a different sensory and affective response. However, as these articles demonstrate, despite these categorical differences, hybrid forms of 'stained glass' proliferated: industrial machine-made glass and mouth-blown artisanal glass could coexist. And varieties of glass - seedy glass (bubbled) or streaky glass (internal streaks of colour) - added to the vocabulary of the glassmaker and designer. And coloured glass could be scopically dramatized with electric light as a public signal or optically transformed by being viewed with a lens by a single viewer.

These twelve articles approach nineteenth-century stained glass in different but overlapping ways. Three themes emerge: first there are those articles concerned with civic iconography, with ambitious public monuments and displays - I think of these as the rhetorical group. Then there are those where technical experiment and change creates the unique character of nineteenth-century stained glass - I think of these as the empirical group. A further group explores ideological design, which in many though not all cases annex the forms of popular glass culture to explore the possibilities of coloured glass - I think of these as the optical group. Medievalism, ecclesiastical politics, and colonial values and ideas of empire enter pervasively into almost all these themes. But they are shaped by the particular context in which they appear.

To turn to the first group. Looking at Jasmine Allen's images of the lost scheme of monumental stained glass windows for what is now the Victoria and Albert Museum, it is hard to overestimate the immense civic pride, ambition, and sheer vision of Henry Cole, the man who masterminded these examples of public glass ('The Union of Science and Art: Stained Glass Windows for the South Kensington Museum'). They were located in dramatic spaces (the thoroughfare of the North Staircase) or else in accessible areas such as the refreshment rooms. The narrative they tell is that of one of the optimistic strains of the Great Exhibition of 1851, the story of a successfully supervised, managed democracy educated in understanding the union of a binary culture - art and industry, science and art, the Bible and modernity. The windows Allen's scrupulous archival research has uncovered stress a respect for manual work, the work of hands. Reuben Townroe's Trades window (1866) and Francis Wollaston Moody's Union of Science and Art window (1866) both endorse labour - in Moody's case the blacksmith, potter, and metalworker - supported with biblical quotation and, above all, allegory. Wisdom with a book and torch oversees this 
window. Allegory, scorned after Coleridge, comes into its own in painted glass: it constitutes the union of another binary - material form and abstraction. Celebrating work already becoming archaic with industrial process, the allegorical figure in coloured glass is transfused with transmitted light in a way that performatively demonstrates the union of light and coloured matter and the possibility of materializing, actually living, an abstraction such as Wisdom. It would be easy to reduce this iconography to bourgeois sentimentality, nostalgia, and coercive didacticism (and these may all be there), but this would be to refuse to see the imaginative possibilities literally embedded in it. For Cole this was a modern form, just as he carefully trained up modern artists from the Schools of Design to lead the way in stained glass.

Veronica Smith's 'Stained Glass and the Victorian Town: Rochdale Library, Museum, and Art Gallery' demonstrates the power of civic pride and local democracy at a later time, 1884 and 1903, when the glass decorations of the library were created through a substantial donation from a local donor. The narrative here is an exuberant story of the convergence of local and national culture. And rather than medievalism and ecclesiastical themes, gender and class are uppermost, mediated, especially in 1903, through art nouveau techniques. What it shares with the South Kensington Museum is a belief in popular education and the capacity of a public to assimilate both the intellectual and sensory aspects of painted glass. James Ogden, the patron, spoke of 'pleasure and instruction' as the aim of the new glass work, and this well-worn phrase encompassed the creation of images of female figures - George Eliot, Elizabeth Barrett Browning, Mary Somerville (science again), Anna Jameson, and Charlotte Brontë in the Women's Reading Room, and a range of literary figures in the Men's - Macaulay, Gibbon, Grote, Bacon, Addison, Defoe. What is unexpected here is the juxtaposition of local figures with poets such as Byron, a local Lancashire dialect satirist, 'Tim Bobbin', and Edwin Waugh, narrator of stories of working-class life. The confidence that induced Rochdale to rival Manchester Town Hall is at work in the employment of local craftsmen and the choice of an immense variety of types of glass and technique, industrial and mouth-blown, particularly in 1903, when the elements and the sciences of chemistry, geology, astronomy, and hydroelectricity were incorporated into a complex and imaginative fusion of glass types. Rather than the earlier techniques of mimesis, the makers used the intrinsic qualities of glass itself to render the blue gradations of water and sky - as if glass was now being an element as much as representing it. Like Cole's allegories, this made new demands on the spectator.

Michael Ledger-Lomas, in 'Stained Glass and the Victorian Monarchy', takes us into the arena of ecclesiastical glass and medievalism very different from the secular glass discussed above. The windows and artists he examines, most notably Charles Eamer Kempe's work in 
Southwark Cathedral, are as much the vehicle of civic ideology as those monitored by Cole and Rochdale except that they are explicitly theological in their conviction that church glass could foster the union of Church and State - another binary - and the interdependence of the monarchy and religion. In this sense they are examples of rhetorical glass. In order to offer a narrative of unity, Kempe and his patron, William Thompson, rector of the cathedral, researched an ecclesiastical and secular early English history that would offer a narrative of local and national conservatism Mallinger, Charles I, Laud, and Bunyan represented the first; Chaucer, Gower, Goldsmith, and Johnson the second. The fact that Bunyan's presence took some explaining suggests why the belated attempt to see British culture through the glass of totalizing national ecclesiastical traditions was too partial to be inclusive, despite the careful refusal to foreground the personal figures of the monarchy. What this attempt does show, however, is that in the nineteenth century's use of stained glass to mediate ideology, images of the human figure and an iconography of known persons were central to the narrative. Biography and ideology go together.

The same is true of Alex Bremner's 'Colonial Themes in Stained Glass, Home and Abroad', which argues that glass transmits light and colonial values throughout the colonies. Both materials and ideologies were exported. Indeed, these flow both outwards and inwards, where the Gothic Revival is a pan-imperial phenomenon, and endorses British imperial hegemony, inevitably racist, as far as Sydney and as near as Winchester, both territories organic parts of Greater Britain. The Great Hall in the University of Sydney celebrates images of Oxbridge as a myth of origins; Winchester Cathedral commemorates the second Boer War. The narrative, or rhetoric, as I have called it, uses glass to assert a white settler narrative of collective citizenship stretching from home to colony that valorizes selfsacrifice and martyrdom.

Perhaps these last two articles suggest that coloured glass can be an all too coercive transmitter of ideology by virtue of the sensory imprint of brilliant transparencies that override conscious control. I am not sure about this: the static nature of the glass image suggests at once its permanence and its impotence, what Jacques Rancière has called in The Future of the Image its visible semblance and 'dissemblance', its reality and unreality.' All ideology involves poignant hopes and fears in its occlusions, denials, and assertions: it is possible, contemplating the static image, to see round or through these coercive hopes and wishes and their historical origins. The wishes of the maker of ecclesiastical stained glass and the emigrant are alike exposed.

${ }^{1}$ Jacques Rancière, The Future of the Image, trans. by Gregory Elliot (London: Verso, 2013), p. 7 . 
An ancient material though it was, the manufacture of glass went through massive changes in the nineteenth century. My second group attends to these material transformations and new techniques. Thea Goldring, in 'Recovered or Perfected: The Discourse of Chemistry in the Nineteenth-Century Revival of Stained Glass in Britain and France', charts the diverging paths of glass science in the two countries. The art and science binary occurs again, but this time in the debate on the degree to which chemistry was germane to the production of coloured glass. Still in the Enlightenment tradition, early nineteenth-century French coloured glass specialists saw the chemistry of colour in academic ways, but progressively abandoned explicit chemical formulas so that by the 188 os chemistry was peripheral to accounts of glassmaking as the scientific account of glass was superseded by an aesthetic reading of it. In Britain the reverse was the case: rule-of-thumb glass recipes dominated in the early part of the century, but by the end of the century glassmaking treatises such as those by Henry James Powell and Henry Chance made in-depth chemical analyses of glass in order to return to ancient formulas and historical accuracy. What is fascinating about this dynamic, though, is that at all times there was an emphasis on achieving 'brilliancy and transparency' and, in particular, on achieving what Goldring calls 'a modern vitreous rainbow', whether the glassmakers believed themselves to be returning to the past or advancing modernity. Glassmakers worked towards new vitreous techniques whether reclaiming or departing from the past.

What we carry away from this is the extreme self-consciousness of glassmakers and technicians in the nineteenth century - and that coloured glass is an ideologically disputed material. Sarah Brown in 'Medieval Stained Glass and the Victorian Restorer' also describes the move to chemistry in the latter part of the century and demonstrates how two entirely different methods of restoring medieval stained glass were valorized. There was a move from rather brutal modernizing of stained glass earlier in the century, often but not always by artisanal plumber-glaziers, to a careful scholarly historicism that abjured the first. It was a move from wholesale replacement with modern glass to a new aesthetic and to meticulous historicist reconstruction where the original was preserved. There was an outcry in 1868 when the Chance brothers desecrated St Mary, Fairford with modern glass replacement, eliminating the features of the old glass. When such replacements occurred, parts of the old window, heads in particular, would be sold on to collectors by the restorer. Craft and commerce were in conflict. In this new preservation movement, the specialist treatise and secular societies (for example the Society for the Protection of Ancient Buildings) had a major role rather than such liturgical bodies as the Camden Society or the Ecclesiological Society, bodies motivated by religious readings of stained glass. The scholar-artists of the Arts and Crafts Movement superseded both the commercial restorers and the liturgical bodies. Paradoxically, 
the Victorian glass we now value was much less important to these men than ancient medieval glass, meaning that they were unconcerned about its destruction. What constituted authenticity changed over the century.

Martin Crampin endorses this understanding in 'Appreciating Variety in Nineteenth-Century Ecclesiastical Stained Glass'. He points to the prolific range and variety of style and experiment in the Great Exhibition of 1851. He charts a range of styles and techniques throughout the century, and introduces names, some of which appear in other parts of this collection of articles, that range way beyond the popularly known figures of the Pre-Raphaelites - William Wailes, John Richard Clayton, Henry Holiday, R. T. Bayne, J. W. Brown, Charles Eamer Kempe, Charles Winston, and Christopher Whall. What emerges as the central question is analogous to Sarah Brown's enquiry about authenticity - what constitutes authentic Gothic, authentic medievalism? And in addition to the question of what dates historical Gothic could be said to occupy, what are the authentic techniques and design features associated with this form? The answers were eclectic and diverse. Thus the single figure, geometrical pattern, foliate patterns, pictorial design, specific range of colours (red, blue, yellow, green), kinds of enamel, and 'silvery delicacy' in late Gothic were all features discussed and canvassed at different times. Part of this unstable mix he attributes to the way coloured glass occupied the boundaries between art, craft, industry, and business, just as its creation depended on engineers, technicians, cartoonists, designers, painters, and glaziers. It is a uniquely in-between substance.

Tom Küpper records another kind of in-betweenness - the inbetween of amateur and professional - in his account of the ambitions of amateur stained glass creators, 'Amateur Stained Glass in English Churches, $1830-80$ '. What these extraordinarily ambitious figures reveal is the astonishing range of techniques, some complex indeed, that amateurs had at their disposal - and developed at their own cost. Cutting, firing, and leading all demanded resources. The nineteenth century created a bank of stained glass forms, designs, and techniques that could be exploited by the intrepid and certainly by these ferociously serious amateurs. Painting on glass, mosaic, and enamel were all forms taken up. Many of the male amateurs were clergymen, or the well-financed aristocratic Sutton brothers who created over twenty-five windows, among them the west window of Lincoln Cathedral. Astonishing is the number of women, equal to the number of men (forty-two), who created stained glass artefacts for churches. From Sophia Musters who created an enamel-painted window in the style of Tintoretto, with herself as the Virgin, for St John's, Colwick (1817), to Lucy Rickards, who designed, painted, and glazed six tall nave windows, the resourcefulness of these women, usually institutionally tied to the church, was extraordinary. 
Finally, to turn to what I have called the optical group, three writers consider coloured glass whose larger context is nineteenth-century optical culture and its technologies and visual effects: Sally Rush, 'Seeing Red'; Jim Cheshire, 'Remediation, Medievalism, and Empire in T. W. Camm's "Jubilee of the Nations" Window at Great Malvern Priory'; and Karen Burns, 'Time and Telegraphy: Nineteenth-Century Contexts for Stained Glass'. All break down the categorical distinctions between high art and popular culture in fascinating ways.

John Martin's Belshazzar's Feast is the centre of 'Seeing Red', or rather, the painting's redaction as a painting on glass with vitreous materials made by Martin himself. A serious aesthetic experiment with light, it reminds us that the mosaic and leaded structure of stained glass was not the only form in which coloured glass was experienced by the Victorians. Rush explores various genres with a family resemblance to Martin's virtuosic experiment with transparency, which he himself rightly defended as a work of art in itself - the mezzotint, whose engraving process on copper overdetermines light and shade, and Gainsborough's box, where backlit transparencies also valorized light and shade. Like Loutherbourg's Eidophusikon in the late eighteenth century, these optical devices not only intensified the eye's scopic experience by intensifying brilliance and transparency but introduced temporality into spectacle by making visual perception a 'light event' in real time. The use of magnifying lenses that created depth and isolated discrete parts of the picture, but could also be moved over its surface, announced another way of seeing that depended on the virtuosity of transmitted light. Optical and psychic intensity worked together as the drama of light in lightning and fire in Martin's painting foregrounded the light that was both subject of the glass painting and enabled it to come into being.

Jim Cheshire invokes the term 'remediation' from cultural studies the way a form or material as a medium draws attention to itself in a new context (defamiliarization is a process that also hovers here) - in order to think about T. W. Camm's Jubilee window of 1887 . Here the remediating/ remediated medium is photography. He considers the strange combination, contradiction indeed, of medievalism and allusion to modern industry, of providential imperial expansion and biblical reference - the tropes of contemporary colonialism mediated through the archaic material of medieval stained glass. There is, he points out, an overdetermined emphasis on the representation of materials produced by subject colonies (as if the designer is conscious of his own experiments with the materiality of glass), just as there is an attempt at representation that is less stylistically medieval than an uneasy attempt to make archaic stained glass attain a form of realism both in colour and line. The element or medium that makes these discrepancies readable is photography. He argues that much of the portraiture owes itself to Camm's use of photography, but also that the archaic 
processes of production of stained glass and the modern photograph run parallel: both depend on transmitted and restricted light for the transposition of images into legibility. An iconography in which the liberated slave justifying empire is transmitted through Gothic conventions and mediated by photography puts modernity and the past in a new relationship. As I understand it, he thinks of this as an integrated field, but an integrated field that was precarious.

Kate Burns's complex study of the lunette entry point of Flinders Street Station in Melbourne, the glass arch through which all travellers passed to their destinations, brings together a number of disciplines and technologies - communications and network theory, racial thinking, organic design, spectacle, electricity, telepathy, biological memory, and optical glass culture. Behind her thought is Walter Benjamin's dream world of spectacle and consumption, and Adorno's understanding of commodity, but she puts this in the wholly new context of colonial ethnography. She argues that the electrical illumination and organic 'biological' design of the lunette at this crucial transition together created not simply signified meanings, but meanings that somatically entered the white settler traveller. They persuaded him or her of a racial and biological memory, a hereditary organic connection with a primal and superior British identity. This, she argues, is inherent in late-century Arts and Crafts thinking and aestheticism.

\section{A phenomenology of coloured glass}

This grouping, then, is the way one can read this very challenging collection of articles in an attempt to chart the different kinds of thinking they explore. As I read I began to wonder what, learning from this collection, a phenomenology of stained/coloured glass in the nineteenth century would look like.

To begin with it would involve close looking, close seeing. In literary studies we are familiar with the idea of 'close reading', current since the days of I. A. Richards. This is often mistaken for a way of merely eliciting a sensitive, meticulously attentive account of the text's language, redescribing the text, with the unsaid epithet 'old-fashioned' attached to it (close reading is for the wrinklies). On the contrary, Richards thought of close reading as a rigorous way of expelling misreading and misapprehension, a way of defending ourselves against ideology. In fact, rigorous close reading is simply the basis of any kind of critical reading. An analogous practice occurs in art history. When I think of the analyses of Michael Fried and T. J. Clark, their capacity to read detail and spatial relationships, their sensitivity to the medium of paint or stone, I believe that a similar sensitivity to the medium of coloured glass is already developing. 
Such close looking would encounter the many genres of coloured glass. The ecclesiastical window and its biblical thematics is the Ur-example of stained glass in the nineteenth century. This is unsurprising, given the work of the Ecclesiological Society (the Cambridge Camden Society) and other architectural associations. But as this collection demonstrates, secular glass display and popular optical devices (from photography to the diorama) are part of the nineteenth century's glass vocabulary. Churches and fairgrounds alike displayed coloured glass. Domestic coloured glass is also important. (My own house's porch has two green and purple glass panels comprising a red flower in a leaded circle at the centre of each, the pistil cunningly made from a 'bull's eye', the circular break point of the blowpipe.) Writers in this collection have noted the immense variety of coloured glass genres and techniques in the Great Exhibition of 1851.

Clearly, a taxonomy of coloured glass genres and a reading of their iconography is important. But a phenomenology would start from the nature of stained glass as a material, and the response it dictates as a material. As I read these articles two or three passages from literary texts came to mind. I shall turn to them to elicit a material reading of coloured glass.

First is Ruskin, who was a subsidiary to the design of a window in Camberwell Church, ultimately giving way to the more experienced designer, Edmund Oldfield, he tells us in Praeterita (1885-89). He did, however, execute a mosaic design of subjects in 'purple and scarlet'. ${ }^{2}$ A rather gauche composition written at sixteen condemns the heavy Gothic of Rheims Cathedral but excuses the windows - 'But in the nave I | Stared at the windows purple, blue, and gold' (p. 221). Later, Ruskin writes of the 'jewel windows' of a missal: 'For truly a well-illuminated missal is a fairy cathedral full of painted widows' (p. 315). The sheer intensity and brilliance of colour, the 'vitreous rainbow' described in one of the articles above, is Ruskin's first requirement of the conventional ecclesiastical stained glass window, a requirement seemingly transcending all others. Nothing muted, nothing understated, is contemplated. This is a norm. He wants a kind of hypervisibility. Felicia Hemans, also writing of the Rheims windows in 'Joan of Arc in Rheims' (in Records of Woman, 1828), offers this brilliance as an oxymoron: 'Within, the light, | Through the rich gloom of pictured windows flowing'. ${ }^{3}$

Hemans adds something else to Ruskin's desiderata - the flow of light. Coloured glass is unique in setting up a double experience. The viewer gazes at the coloured materials but not as at a conventional picture, for the viewer is simultaneously aware of the transmission of light by glass, a flow of light through the visual image. In clear glass transmitted light also

${ }^{2}$ John Ruskin, Praeterita, ed. by Francis O'Gorman (Oxford: Oxford University Press, 2012), p. 244 .

3 'Joan of Arc in Rheims', in The Poetical Works of Mrs Hemans, ed. by William Michael Rossetti (London: Ward, Lock, 1912), p. 129. 
enables vision, but its total transparency suppresses this perception. In coloured glass the scopic experience of transmitted light is intrinsic to the act of looking. All picture and image viewing, of course, is enabled by light, but stained glass necessarily brings this to awareness, an overdetermined awareness, because without it transparent stained glass colour and imaging could not come into being. Hemans writes that the flow of light through coloured glass 'Tinged with soft awfulness' the gathered congregation. Stained glass transfers its colour to the bodies of spectators or anyone within its field. It becomes a somatic experience not simply associated with the eye alone. Moreover, because light is always in a state of movement and change, a consciousness of experiencing colour and the backlit image in real time gives a peculiar intensity to coloured glass viewing experience and differentiates it from all other kinds of looking. This living movement of light is what gives aura to stained glass. In the nineteenth century's age of mechanical production, it must have been one of the few forms of material to retain the aura Benjamin famously thought was lost to his culture. ${ }^{4}$ This must surely be the spiritual motivation of much ecclesiastical stained glass, the living flow of light, but the same real-time aura is present in secular glass too. It is what brings a psychic and optical intensity to looking at coloured glass.

Another literary text enlarges these possibilities of looking, Katherine Mansfield's short story, 'Prelude' (1918). This is a text of early modernism but looks back to the nineteenth century. The child Kezia returns to the empty house she is forced to leave:

The dining-room window had a square of coloured glass at each
corner. One was blue and one was yellow. Kezia bent down to
have one more look at a blue lawn with blue arum lilies grow-
ing at the gate, and then at a yellow lawn with yellow lilies and
a yellow fence. As she looked a little Chinese Lottie came out
on to the lawn and began to dust the tables and chairs with a
corner of her pinafore. Was that really Lottie? Kezia was not
quite sure until she had looked through the ordinary window. 5

Here, I think the same conditions as I have described above hold good in this lyrical paragraph, but instead of looking at, the viewer looks through. Looks through at a world transformed. Blue, the fastest moving colour of the spectrum, charges the world with intense affective colour, the colour of sadness. Kezia's experiment in looking then turns to yellow, a more sluggish part of the spectrum, and her sister becomes a yellow 'Chinese'. Colour changes the body: Lottie becomes one of the invasive bodies that haunted the imaginaries of Australia and New Zealand, the yellow peril.

4 Walter Benjamin, 'The Work of Art in the Age of Mechanical Reproduction', in Illuminations, trans. by Harry Zohn (New York: Schocken, 1968), pp. 217-51.

5 Katherine Mansfield, Prelude (London: Hesperus, 2005), p. 6. 
Kezia looks through the 'ordinary' window to assuage her alarm and reassert ordinariness. The intensity of the spectrum upsets norms and calls into question norms themselves even though hastily reasserted here. Yet the blue glass and the yellow glass are in tension with one another, and this tension cannot be eradicated by resorting to the pure transparency of clear glass. Coloured glass alters our affective world and offers significations that are culturally made, but with an intensity that is destabilizing and reaches into the unconscious. Kezia is suddenly confronted with seeing a blood relation through racial peril: the turn to transparency will not suppress the uneasy questions the colour precipitates.

Some critics - Jonathan Crary was one of the earliest to do so in Techniques of the Observer (1990) - have seen in the psychic vulnerability created by optical glass culture an occasion for exploitation, as popular optical devices, deemed the product of mechanistic technology, become an occasion for social control and limit on a passive consciousness. I do not share this view. In the case of coloured glass, its mobility as a sensory experience makes it constantly unpredictable so that it escapes from a univocal regime. Though ideology may seem permanently annealed into stained glass, which certainly transmits it, the necessity of looking at an image we know is coming into being through light and its transitory changes makes it provisional, capable of revision, or re-vision. (That is surely why we can read ideology at all.) Coloured glass is arousing and pre-empts passivity by making interrogation possible.

My last example is from George Eliot's Daniel Deronda (1876) and demonstrates something of the unpredictability of stained glass. At the Mallinger Christmas house party a group visits the stables, housed in a deconsecrated chapel. Transmitted light from the remaining ancient ecclesiastical windows falls on the flanks of the horses, so that aristocratic bloodstock and religious imagery are bizarrely in conjunction: 'in the dusty glazing of the windows there still gleamed patches of crimson, orange, blue, and palest violet. ${ }^{\prime}$ A profoundly secular society, reducing religious experience to the aesthetics of the spectrum, is one reading the text asks for. But another suggests the shock of aura and the still living arousal that spiritual experience can mediate.

I would like to write about the glorious Renaissance stained glass windows of Arezzo Cathedral that tell the story of the life of Jesus, the late nineteenth-century domed glass roofing of Baltimore Station, Maryland, the modern abstract mosaic of the window in Cologne Cathedral designed by Gerhard Richter - but I have run out of time. I hope nevertheless that this suggests how much more there is to say about stained glass. The articles in this collection are part of an endless discussion.

${ }^{6}$ George Eliot, Daniel Deronda, ed. by Edmund White (New York: Random House, 2002), p. 379 . 